\title{
Advances in Understanding of the Pathogenesis of Acute Respiratory Distress Syndrome
}

\author{
Charles Sharp ${ }^{a} \quad$ Ann B. Millar ${ }^{a, b} \quad$ Andrew R.L. Medford ${ }^{a, b}$

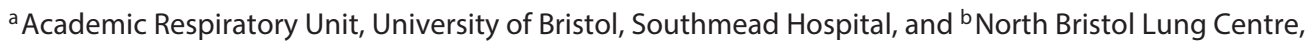 \\ Southmead Hospital, Westbury-on-Trym, UK
}

\section{Key Words}

Acute respiratory distress syndrome - Acute lung injury .

Pulmonary oedema $\cdot$ Epithelial permeability

\begin{abstract}
The clinical syndrome of acute lung injury (ALI) occurs as a result of an initial acute systemic inflammatory response. This can be consequent to a plethora of insults, either direct to the lung or indirect. The insult results in increased epithelial permeability, leading to alveolar flooding with a proteinrich oedema fluid. The resulting loss of gas exchange leads to acute respiratory failure and typically catastrophic illness, termed acute respiratory distress syndrome (ARDS), requiring ventilatory and critical care support. There remains a significant disease burden, with some estimates showing 200,000 cases each year in the USA with a mortality approaching $50 \%$. In addition, there is a significant burden of morbidity in survivors. There are currently no disease-modifying therapies available, and the most effective advances in caring for these patients have been in changes to ventilator strategy as a result of the ARDS network studies nearly 15 years ago. Here, we will give an overview of more recent advances in the understanding of the cellular biology of ALI and highlight areas that may prove fertile for future diseasemodifying therapies.

(c) 2015 S. Karger AG, Basel
\end{abstract}

\section{Introduction}

The complex clinical syndrome of acute lung injury (ALI) occurs as a result of an initial acute systemic inflammatory response. This can be consequent to a plethora of insults, either direct to the lung or indirect. The insult results in increased epithelial permeability, leading to alveolar flooding with a protein-rich oedema fluid. The resulting loss of gas exchange leads to acute respiratory failure and typically catastrophic illness, termed acute respiratory distress syndrome (ARDS), requiring ventilatory and critical care support.

The syndrome was first recognised in a military context; Ashbaugh et al. [1] first described and named ARDS in 1967. The first detailed description of what can be recognised as ARDS was published in 1915 by a physician in the Canadian military [2]. There remains a significant disease burden, with some estimates showing 200,000 cases each year in the USA with a mortality approaching $50 \%$ [3]. In addition, there is a significant burden of morbidity in survivors; $80 \%$ of patients in one cohort demonstrated reduced diffusing capacity at 1 year from recovery, with reduced health-related quality of life (HRQL) [4], while significant reductions were seen in 6-min walk distance and HRQL measures after 5 years of follow-up in a separate cohort of survivors [5].

\section{KARGER 125}

(c) 2015 S. Karger AG, Base

0025-7931/15/0895-0420\$39.50/0
Dr. Andrew R.L. Medford

North Bristol Lung Centre and University of Bristol Level 6, Gate 10, Brunel Building, Southmead Hospital Westbury-on-Trym, Bristol BS10 5NB (UK)

E-Mail a.medford@ rcpe.ac.uk 
Table 1. Clinical trials in ARDS

\begin{tabular}{|c|c|c|c|c|}
\hline Intervention & Study & Year & $\begin{array}{l}\text { Population (variable } \\
\text { definitions of ARDS } \\
\text { used) }\end{array}$ & Outcome \\
\hline Lung-protective ventilation & ARDSnet [6] & 2000 & $\operatorname{ARDS}(\mathrm{n}=861)$ & Decreased mortality \\
\hline High positive end expiratory pressure & Brower et al. [7] & 2004 & $\operatorname{ARDS}(n=549)$ & No difference in mortality \\
\hline Nitric oxide & Taylor et al. [8] & 2004 & $\operatorname{ARDS}(\mathrm{n}=385)$ & No difference in mortality \\
\hline Methylprednisolone & Bernard et al. [9] & 1987 & $\operatorname{ARDS}(\mathrm{n}=99)$ & No difference in mortality \\
\hline Methylprednisolone & Meduri et al. [10] & 2007 & $\operatorname{ARDS}(\mathrm{n}=91)$ & $\begin{array}{l}\text { Reduced ventilator days (limitations } \\
\text { related to study design) }\end{array}$ \\
\hline Prone ventilation & PROSEVA [11] & 2013 & $\operatorname{ARDS}(\mathrm{n}=466)$ & Decreased mortality \\
\hline$\beta_{2}$-Agonists & BALTI-2 [12] & 2012 & $\operatorname{ARDS}(\mathrm{n}=326)$ & Increased mortality \\
\hline High-frequency oscillation ventilation & OSCILLATE [13] & 2013 & $\operatorname{ARDS}(\mathrm{n}=548)$ & No difference in mortality \\
\hline High-frequency oscillation ventilation & OSCAR [14] & 2013 & $\operatorname{ARDS}(\mathrm{n}=795)$ & No difference in mortality \\
\hline Extracorporeal membrane oxygenation & CESAR [15] & 2009 & $\operatorname{ARDS}(\mathrm{n}=180)$ & $\begin{array}{l}\text { Decreased mortality with referral } \\
\text { for consideration of ECMO }\end{array}$ \\
\hline Simvastatin & HARP-2 [16] & 2014 & $\operatorname{ARDS}(\mathrm{n}=540)$ & No difference in mortality \\
\hline Neutrophil elastase inhibition & STRIVE [17] & 2004 & $\operatorname{ARDS}(\mathrm{n}=492)$ & Increased mortality \\
\hline
\end{tabular}

Table 2. ARDS definitions

\begin{tabular}{lcl}
\hline ARDS severity & $\mathrm{PaO}_{2} / \mathrm{FiO}_{2}{ }^{\mathrm{a}}$ & Mortality, \% \\
\hline Mild & $200-300$ & 27 \\
Moderate & $100-200$ & 32 \\
Severe & $<100$ & 45 \\
\hline
\end{tabular}

${ }^{\mathrm{a}}$ On PEEP 5+. ${ }^{\mathrm{b}}$ Observed in cohort.

There are currently no disease-modifying therapies available, and the most effective advances in caring for these patients have been in changes to ventilator strategy as a result of the ARDS network studies nearly 15 years ago [6]. Relevant clinical trials in ARDS are summarised in table 1.

Here, we will give an overview of more recent advances in the understanding of the cellular biology of ALI and highlight areas that may prove fertile for future diseasemodifying therapies.

\section{Definitions of ARDS}

To facilitate research into ARDS pathogenesis and before development of treatments could proceed, a clear clinical definition of the syndrome was needed. This was developed in 1994 by the American-European Consensus Conference (AECC) on ARDS [18]. The AECC definition of ARDS was updated in 2012, with the Berlin Definition to provide a more accurate prediction of mortality [19]. This definition now categorises ARDS as mild, moderate or severe (table 2).

The new definition describes an acute onset of symptoms ( $<7$ days), with bilateral radiographic opacities consistent with pulmonary oedema, but not fully explained by cardiac failure or fluid overload. There is also a requirement in the new definition for the need for positive end-expiratory pressure. This definition has not been without controversy [20].

In addition to a clinical definition, there is a need for histopathological descriptions of the syndrome to reinforce this. The histological changes are characteristic and represent a common end point of the process of diffuse alveolar damage. The progression of ARDS has been broken down into phases (fig. 1); however, they can occur concurrently. These are coordinated by a cascade of inflammatory mediators, ultimately resulting in the generation of reactive oxygen and nitrogen species along with proteolytic enzyme release. This gives the end result of tissue destruction and respiratory failure.

The early, exudative phase demonstrates diffuse alveolar damage, with disruption and loss of epithelial and endothelial cells and characteristic protein-rich alveolar oedema. The proliferative phase that follows sees formation of hyaline membranes on the epithelial side of the basement membrane, with a cellular infiltrate into the alveolar spaces comprising neutrophils, macrophages and erythrocytes. 
Fig. 1. Phases of ARDS.

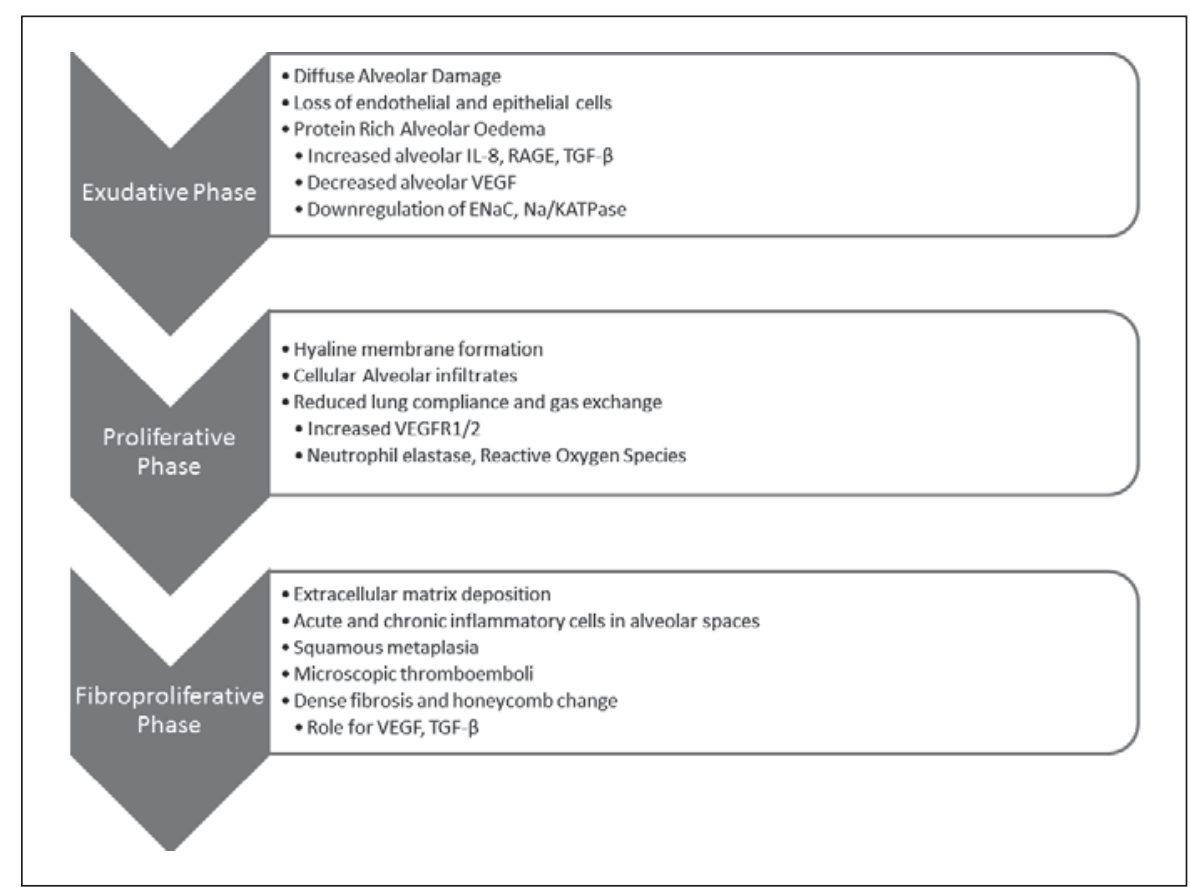

These changes lead to a loss of lung compliance and impaired gas exchange. While there can be resolution, many cases progress to respiratory failure in the context of a fibro-proliferative phase, marked histologically by extracellular matrix (ECM) deposition with acute and chronic inflammatory cells, including fibroblast and type II alveolar epithelial cell proliferation within the alveolar space, with associated squamous metaplasia and microscopic thromboemboli. The latest phases of injury demonstrate remodelled lung architecture with dense fibrosis and ultimately honeycomb changes in the lung [21].

Recently, Thille et al. [22] demonstrated that histological changes correlated with the duration of ARDS in a post-mortem study including 159 patients over a 20-year period meeting the clinical definition of ARDS. They seldom saw fibro-proliferative changes within the first week; however, such changes began to predominate, especially beyond 3 weeks. Fibrosis was more prevalent in cases with lung injury as a consequence of a direct insult. Whilst the conclusions to be drawn from this study are limited by its bias towards the fatal end of the ARDS spectrum, this still highlights the need to focus treatments on the early phases of lung injury, to arrest the process and thereby mitigate the burden of disease on survivors.

Investigation of ARDS is challenging; histological diagnosis is usually not possible or feasible due to the need for a surgical lung biopsy. Animal models are varied [23], and no single model reproduces entirely the syndrome seen in clinical practice. Further information can be obtained from broncho-alveolar lavage (BAL) fluid to determine the alveolar milieu. This has been shown to be safe in a study of 162 ventilated patients with ARDS in a single centre [24], and in a comparison of BAL and endotracheal aspirates in the diagnosis of ventilator-associated pneumonia, which included a subgroup of patients with ARDS [25]. There are few reliable models of the late phases of the syndrome, making the determination of mechanisms underlying the fibroproliferative phases experimentally challenging. The heterogeneity of ARDS undoubtedly contributes to the limited progress made in developing therapeutic options.

\section{The Alveolar Capillary Membrane}

The process of ALI results histopathologically in disruption to the interface between the alveolar epithelium and the associated capillary endothelium, known as the alveolar capillary membrane (ACM; fig. 2). This also comprises ECM and other cells, including alveolar macrophages and fibroblasts. The configuration of the ACM optimises surface area and thickness for efficient gas exchange, while maintaining mechanical properties of compliance to facilitate ventilation. 
Fig. 2. The ACM in health. Adapted and modified from Grommes and Soehnlein [26] and Ware and Matthay [21].

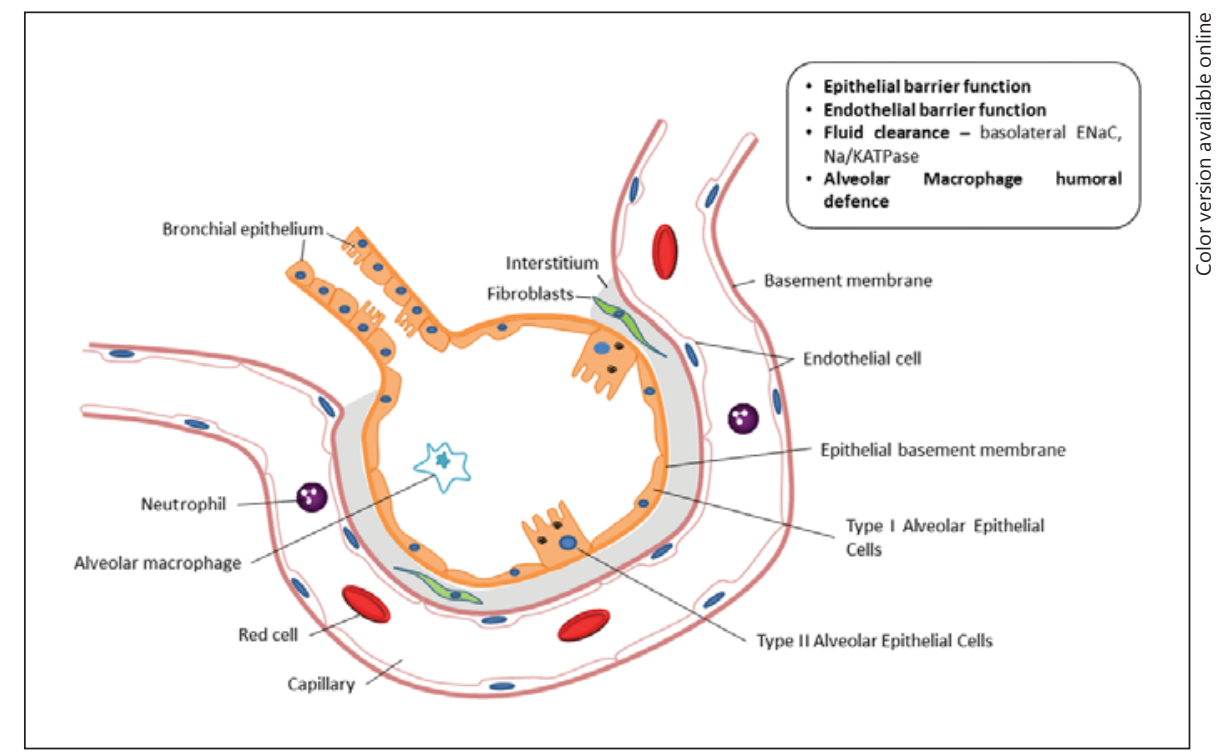

The respiratory epithelium is in health at the heart of host response to lung injury and infection. This comprises type I and II alveolar epithelial cells. Type I cells account for $80 \%$ of the alveolar surface area, but only $20 \%$ of the total epithelial cells, with a thin morphology ideal for gas exchange. Type II cells, which are responsible for secretion of surfactant and regulation of epithelial fluid balance, are cuboidal. They represent the inverse proportions, $20 \%$ of the surface area and $80 \%$ of the total epithelial cellular population. Both cell types have functions in host defence and immunity; the expression of Toll-like receptor- 2 and 4 on the surface of type II cells [27] suggests a role in protection against bacteria. Type II cells are also more resilient; following injury, to which type I cells are susceptible, the type II cells proliferate and differentiate to type I cells to re-epithelialise the barrier function of the alveolus.

The counterpart to this within the ACM is the endothelium of the associated vasculature. This is closely apposed to the type I cell by fused basal lamina to optimise conditions for gas exchange. The remaining portion of the ACM has a layer of ECM between epithelium and endothelium, involved in liquid and solute exchange. This pulmonary ECM comprises type I and III collagen, elastin and proteoglycans to provide a mechanical framework permitting cyclical volume change in the alveolar unit. This matrix has been shown to be closely involved in a range of processes, including cell survival, proliferation and migration, key processes in the pathobiology of ALI [28].

Advances in ARDS

\section{Pathogenesis of ARDS}

The development of ARDS is underpinned by disruption to the normal maintenance and repair of the ACM. Changes in alveolar fluid transport and clearance in addition to altered endothelial/epithelial permeability lead to alveolar proteinaceous oedema. Changes in the patterns of chemokine expression and cell, especially neutrophil, recruitment and activity, lead to augmentation of these injurious conditions. Alveolar epithelial cell apoptosis worsens physical barrier properties and function of the ACM in gas exchange.

\section{Chemokines and Cytokines (fig. 3)}

Recent advances in the understanding of the pathogenesis of ARDS have been facilitated by a greater understanding of the roles of a variety of chemokines in changes to epithelial/endothelial function, in addition to cell recruitment. The key players in ARDS appear to be interleukin-8 (IL-8), transforming growth factor- $\beta$ (TGF- $\beta$ ) and vascular endothelial growth factor (VEGF), with roles also seen for other mediators such as receptor for advanced glycation end products (RAGE).

\section{Vascular Endothelial Growth Factor}

VEGF is a glycoprotein synthesised and released by vascular endothelial cells, lung epithelium, platelets and leukocytes. It can act to enhance angiogenesis and microvascular permeability through receptor binding [29]. The presence of high levels of VEGF in the normal alveolar 


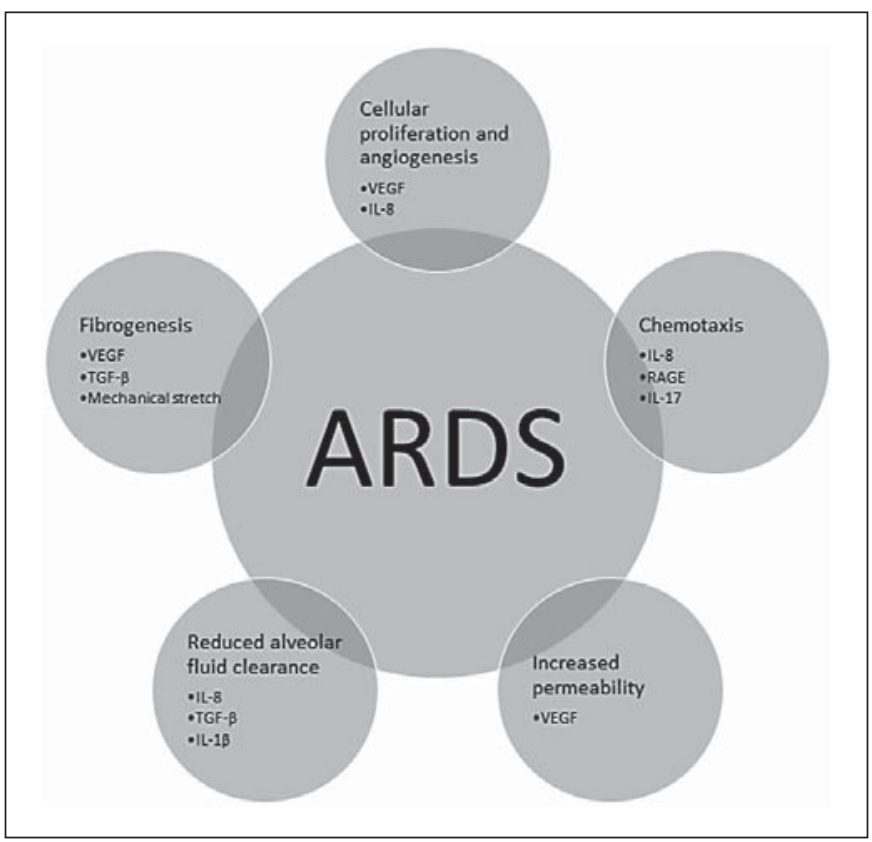

Fig. 3. Chemokines and cytokines in ARDS.

space $[30,31]$ has led to consideration that it is closely involved in processes resulting in a loss of change in the function of the ACM in many forms of lung disease, including ARDS. On a genetic level, a polymorphism associated with a lower plasma level of VEGF was increased in patients with ARDS $[32,33]$. There are alterations in the plasma levels of VEGF, with associated falls in intrapulmonary levels seen in the early, exudative phase of lung injury; these changes normalise in recovery [34]. The observation that alveolar levels of VEGF are twice the level shown to induce angiogenesis [35], with restriction of these processes in healthy lung [36], leads to paradoxical and opposing views of the role of VEGF in normal and diseased lung $[37,38]$. It has been suggested that regulation of the biological activity of VEGF could provide an explanation of previous observations.

VEGF activity can be regulated at several levels; alternative splicing of transcripts from exons 6 to 8 leads to generation of several isoforms, with varying properties $[39,40]$. Furthermore, receptors VEGFR-1 and VEGFR-2 are subject to variable expression in different tissues, and alternative splicing of VEGFR-1 can lead to a soluble form (soluble-fms-like tyrosine kinase, s-FLT), which is inhibitory [41]. Expression of s-FLT has been shown to change in ARDS, with an increase in plasma levels throughout all phases of disease in one study [42]. There is significant upregulation of both VEGFR-1/2 in later, proliferative and fibro-proliferative phases of ARDS [43]. The soluble form, sVEGFR-2 is also detectable in the BAL fluid of patients with ARDS [44], possibly accounting for the reduction in bioactive VEGF in this compartment. This altered expression, along with alterations in the pattern of VEGF isoform expression [45] suggests a role for this regulation of VEGF bioactivity in determining disease.

Recognition of the $\mathrm{VEGF}_{\mathrm{xxxb}}$ isoform family [46], which results in a unique pattern of VEGFR-2 tyrosine phosphorylation, differing from that seen by conventional isoforms, has subsequently led to the observation that this family is not only non-angiogenic, but may be actively anti-angiogenic [47], and therefore may be closely involved in maintenance of the ACM in health and disease. More recently, Eswarappa et al. [48] have described a novel isoform, VEGF-Ax, generated by programmed translational readthrough. This also appears to be antiangiogenic and merits exploration. Further work is needed to establish the roles of these isoforms, which could be fruitful areas for therapies, but have yet to be explored in any detail outside oncological studies [49].

While there is potential for the use of specific antiVEGF biological therapies, such as bevacizumab, in ARDS, there have yet to be any studies, and a recently proposed trial was unable to secure funding to proceed.

There may also be roles in the pathogenesis of ARDS for other members of the VEGF superfamily; platelet-derived growth factor (PDGF) has been found in BAL fluid from a cohort of patients with ARDS. Migration assays were performed on this fluid, and their PDGF and soluble PDGF receptor levels were measured. The BAL fluid was shown to be chemotactic, with inhibition of the PDGF attenuating this cellular migration [50]. This is consistent with the observations in other members of this signalling family.

The VEGF family has been implicated also in fibrogenesis, both in lung injury and in idiopathic pulmonary fibrosis (IPF) [51]. The targeting of the tyrosine kinase family of receptors has been fruitful in IPF, with the development of nintedanib [52], and this may also be an avenue to explore in ARDS. A pre-clinical study in a bleomycin model of lung injury and fibrosis in mice demonstrated attenuation of these with the tyrosine kinase inhibitors imatinib and nilotinib [53]. This was more marked in the case of nilotinib, which is selective for PDGF receptors. There has been little translational work beyond this in PDGF despite the number of years for which it has been recognised to be involved in ARDS. 


\section{Interleukin-8}

IL-8 (CXCL8) is a chemokine with potent properties to both attract and activate neutrophils and has a significant role in ARDS [54], with higher concentrations in BAL fluid from ARDS patients compared to controls and a mortality correlating with this higher concentration. This appears to be especially relevant to the early, exudative phase of ARDS, where IL-8 mediates part of the prominent cellular infiltration seen. Studies examining clinical predictors of ALI found that IL-8 was, along with surfactant protein $\mathrm{D}$, the best performing biomarker in a cohort of 569 patients from the ARDSnet study, with an area under the receiver operating characteristic curve of 0.85 for mortality [55]. Its role in ARDS is complex [56]; its activity appears to be regulated by an anti-IL-8 autoantibody [57], leading to the general hypothesis that overwhelming infection or other insults surpass the capacity of the removal mechanisms. This would result in increased and persisting amounts of anti-IL-8: IL-8 complexes in the lung, leading to the pathological processes underpinning ARDS. These complexes maintain the capacity to trigger neutrophil chemotaxis and respiratory burst/degranulation; thus, they can still trigger an inflammatory response in the lung [58].

In one cohort study seeking biomarkers in ARDS, IL-8 levels were found to be significantly correlated with 28day mortality; those with a detectable level in BAL fluid at baseline had a mortality of $19 \%$ compared with $9 \%$ in those with undetectable levels $(\mathrm{p}=0.02)$ [59]. This was also associated with a greater number of ventilator days, supporting a hypothesis that excessive IL-8 expression may lead to excessive neutrophil-mediated inflammation.

Further evidence of the involvement of IL- 8 is seen from the central role that chemokine (C-X-C motif) receptor 2 (CXCR2) seems to play. This $\mathrm{G}$ protein-coupled receptor for IL-8 (formerly termed IL- 8 receptor- $\beta$ ), mediates neutrophil migration [60], as well as angiogenesis. In one study in humans, after ischaemia-reperfusion injury related to lung transplantation, elevated levels of multiple CXC chemokines [61], including CXCR2, were found in BAL fluid. The same investigators examined a rat model of transplantation, observing that CXCR2 expression paralleled neutrophilic infiltration and injury, while its inhibition led to reduction in this migration and also the graft injury. This is also seen in a CXCR2 knockout mouse model, with hyperoxia-induced ALI; there was significantly reduced neutrophil sequestration and lung injury, giving these mice a survival advantage over the wild type [62]. A novel inhibitor of CXCR1/2 was found to reduce the neutrophilia induced by LPS in both a rat and simian model of lung injury [63]; this has yet to be explored further.

While its involvement in ARDS has been recognised for some time, there have been no published attempts at directly targeting IL-8 in animal models of ARDS. The role of this molecule in ARDS is an area of ongoing research, with further characterisation of the signalling pathways associated with IL-8 required before it can be explored as a potential target for therapies.

\section{Transforming Growth Factor- $\beta$}

TGF- $\beta$ is a key mediator in ARDS, with an impact on epithelial and endothelial permeability through action on protease-activated receptor-1 to promote alveolar flooding [64]. As with other implicated mediators, detection of TGF- $\beta$ in BAL fluid at increased levels in ARDS and the correlation of lower levels with more ventilator and intensive care unit-free days [65] suggest a central role in the pathogenesis of the syndrome. This is also seen in animal models of lung injury - a pancreatitis mouse model demonstrated increased levels in the exudative, early phase and further implicated imbalance of the Smad regulatory axis in the consequent dysregulation of TGF- $\beta$ activity [66].

The mechanism for involvement of TGF- $\beta$ appears to be through changes in fluid handing at the level of epithelial sodium channels (ENaC) [67] and sodium-potassium adenosine triphosphatase (Na/K-ATPase) [68]. Sequestration of free TGF- $\beta$ seems to attenuate alveolar flooding in animal models of ARDS [69]. A recent study implicates TGF- $\beta$ in the persistence of pulmonary oedema in the proliferative phases of ARDS, through disruption of $\mathrm{ENaC}$ complexes [70].

The mechanisms regulating TGF- $\beta$ help to explain some of the apparent dysregulation in disease. It is secreted as a latent complex, bound to latency-associated peptide, which prevents it from binding its receptors. The latent complex is activated by $\mathrm{pH}$, heat, proteases, thrombospondin-1 [71], reactive oxygen species (ROS) and integrins [64]. This complex may have a longer half-life than active TGF- $\beta_{1}[72]$ and may bind its own receptor to exert anti-inflammatory effects via the Foxp3-dependent mechanism [73]. Latency-associated peptide also binds to active TGF- $\beta_{1}$ as a potent inhibitor, acting to regulate its bioactivity [74]. In a bleomycin murine lung injury model, mice with higher levels of latent TGF- $\beta_{1}$ in plasma and lung tissue had attenuated inflammation [75]. This supports the possibility that this mediator could be a thera- 
peutic target, in addition to targeting $\mathrm{ENaC}$ trafficking itself [76].

A further key role of TGF- $\beta$ is in the fibrogenesis seen late in disease. One study demonstrated that BAL fluid from ARDS patients induced myofibroblast differentiation, correlating with TGF- $\beta$ expression [77]. These findings complement the well-recognised role of this molecule in IPF [78] and epithelial-mesenchymal transformation, a component of the process seen in ARDS.

It is important to highlight that, while its role in lung injury has been recognised for many years, there has been no evidence of benefit from targeting the signalling cascade of TGF- $\beta$. This reflects the complexity and ubiquity of this molecule in maintenance of tissue health in most organs of the body.

Receptor for Advanced Glycation End Products

The RAGE has been identified as a marker of alveolar type I cell injury [79]. This molecule is a member of the immunoglobulin superfamily and acts as a multi-ligand receptor involved in propagating the inflammatory response $[80,81]$. Its location in the lung is mainly at the basal surface of type I alveolar epithelial cells, and is most abundant in the lung (though not specific to that organ or cell type). RAGE levels have been shown to be elevated in BAL fluid and serum in murine models of ALI, correlating directly with the severity of the injury. This has also been seen in human subjects, with plasma RAGE levels higher in patients with ALI, than cardiogenic pulmonary oedema or normal subjects [79].

Higher baseline plasma levels of RAGE were associated with worse clinical outcomes (including increased mortality and fewer ventilator-free days) in a large, multi-centre, randomised, controlled trial of ventilation strategy in ALI [82]. Further studies in ARDS patients have shown that soluble RAGE is independently associated with death in ARDS patients, with further evidence that the signalling axis involving high mobility group box 1 and RAGE is involved in poor prognosis of ARDS [83].

The utility of RAGE as a biomarker of ARDS has been further explored, given its predominant lung epithelial source, and in a retrospective case-control study of 100 patients with severe sepsis and no ARDS, compared to 100 with severe sepsis and evidence of ARDS, RAGE was found to have excellent discrimination for diagnosis of ARDS in patients with severe sepsis [55]. The likely alveolar cell source of the RAGE suggests that the degree of AT1 cell injury is an important determinant of outcomes in human ALI.

\section{Neutrophil Recruitment and Activity}

Neutrophilic infiltration of the alveolar spaces and serum neutrophilia have long been observed in ARDS. The concentration of neutrophils correlates with the degree of hypoxaemia and pulmonary vascular permeability, with a higher neutrophilia predicting poor survival [54]. The activation and transmigration of neutrophils is indeed viewed as a hallmark event in the progression of ALI/ ARDS, as the exudative phase progresses into the proliferative phase. IL-8 (discussed above) is a key chemoattractant for neutrophils, in part mediated through CXCR2, and blockade of this axis has been shown to be protective in an acid aspiration-induced lung injury model in rabbits, along with other neutrophil-dependent models of ALI [84-87].

In sepsis-related ARDS, the lymphocyte-derived chemokine IL-17 is a potent neutrophil chemoattractant. Interruption of this signalling pathway can attenuate lung injury, as demonstrated in an ischaemia-reperfusion model in mice, where both IL-17 knockout and antiIL-17 antibodies were protective [88]. This was also seen in an LPS model of murine lung injury; use of anti-IL-17 antibodies resulted in faster resolution of inflammation [89].

The occurrence of ALI/ARDS in neutropenic patients [90], along with the existence of both neutrophil-dependent and independent models of ALI, makes this a contributing, but not obligatory step in the development of this syndrome. The mechanisms underlying neutrophil recruitment are beyond the scope of this review, but are well described elsewhere [26].

One component of the ARDS syndrome may be an excessive neutrophil response to noxious stimuli. One component of this may be an increase in neutrophil extracellular traps (NETs), which are a newly described component of cell death mechanisms [91]. In response to infection or other stimuli, neutrophils emit granule proteins and chromatin. This extracellular fibril matrix carries antimicrobial proteins, including neutrophil elastase and myeloperoxidase from granules, however does not include cytoplasmic proteins. This enables the extracellular killing of microbes as a result of this high local concentration of antimicrobial agents, acting independently of phagocytosis. They are also thought to act as a physical barrier preventing further spread of pathogens. While this aids bacterial trapping and killing, it may exacerbate collateral tissue damage. A study comparing neutrophil with macrophage-depleted mice, in a model of influenza-induced lung injury, demonstrated increased formation of NETs, and further that neutrophils 
from infected lungs induced NET formation, augmenting endothelial damage [92].

There are multiple mechanisms which may explain excessive neutrophil recruitment, and this is likely to vary with the aetiology of ARDS. In virally induced lung injury, the CXCL10-CXCR3 axis is implicated by a study demonstrating that lack of one of the components attenuated virally induced lung injury in mice [93]. The concept of neutrophil priming may also play a role; this is the process whereby exposure to inflammatory or physical stimuli increases subsequent cellular response. In a study in healthy humans, radio-labelled, autologous, unprimed neutrophils were shown to be retained in the lung at a level of $<5 \%$, while $97 \%$ of primed neutrophils were retained at the first pass. In ARDS patients, the de-priming mechanisms observed in healthy subjects (through CD62L expression levels) were reduced, leading to increased numbers of primed neutrophils in the systemic circulation and possibly disproportionate neutrophilic inflammation in the lungs of ARDS patients [94]. While this may indicate a target for the development of future therapies, it also highlights the diversity of the underlying syndrome; this axis may not be a useful target in other aetiologies of lung injury.

The migration of neutrophils to the lung is not uniquely a phenomenon of early ARDS; a murine model of lung injury with LPS showed two phases of chemoattractant patterns. An early phase was characterised by high levels of CXCL1 and CXCL2; however, there was a distinct later phase distinguished by an increase in extracellular adenosine triphosphate (ATP) [95]. This suggests that a cycle of damage may develop, targeting of which could reduce the course of disease in some cases.

Neutrophil secretory vesicles are an obvious candidate for some of the inflammatory damage seen in ARDS. There are 4 granule subsets: azurophilic (primary), specific (secondary), gelatinase (tertiary) and secretory vesicles. Different subsets degranulate at distinct stages of neutrophil migration, and the granule proteins are likely to have an important role in the onset of ALI, particularly induced by Streptococcus pyogenes, in an experiment where the supernatant from activated neutrophils restored the deleterious effects of neutrophils in neutropenic mice [96].

One component of these vesicles which holds an evident role in the pathogenesis of lung injury is neutrophil elastase; the levels of this serine protease are increased in BAL fluid and plasma of patients with ARDS, with levels correlated with the severity of injury [97]. Elastase inhibition has been considered in small clinical trials [98], with some evidence of a protective effect. Its administration in murine models of lung injury has also been shown to induce damage [99], whilst its inhibition is protective. Whether these effects are due to direct noxious effects on the epithelium, endothelium or the basement membrane remains to be determined.

Other components of these vesicles, especially through the generation of ROS have also been implicated; a murine model of influenza-induced ARDS in mice lacking myeloperoxidase showed attenuated inflammatory damage and reduction in leakage of other proteins as detected in BAL fluid [100]. Further studies in animal models of ARDS show that neutrophil-derived ROS, in addition to reactive nitrogen species cause histological lung injury and increased permeability [101].

\section{Extracellular Matrix}

The architecture of the lung and its function depends on maintaining an ECM framework with mechanical properties favourable to ventilation. The ECM is located between the alveolar epithelium and capillary endothelium, with a thickness varying along the length of the air/ blood interface. It is thinnest where the AT1 cell is closely applied to the endothelium by fused basal lamina, whilst it is thicker away from this zone. This area of thicker ECM is responsible for liquid and solute exchange and is thus vital for the maintenance of a healthy alveolar environment. It also comprises interstitial connective tissue (type 1 collagen, type 3 collagen, elastin and proteoglycans) which permits cyclical volume change in the terminal respiratory units. More recently, it has become apparent that the ECM has roles beyond these mechanical properties. There are a range of processes, including cell survival, proliferation and migration, which are influenced by cellmatrix interactions and matrix turnover [102].

One component of the ECM is the family of matrix metalloproteinases (MMPs), which are produced by a variety of stromal, epithelial and inflammatory cells and are capable of degrading all known components of the ECM and also non-ECM substrates including pro-TNF- $\alpha$, proTGF- $\beta_{2}$ and other chemokines. This has effects on the regulation of processes including cell growth, proliferation, survival and migration [103]. The first observation of MMP involvement in ARDS was in the early 1990s, and since then further work has investigated their role in mediating alveolar epithelial-endothelial barrier injury in the acute, exudative and proliferative phases of ARDS and also during lung repair in its aftermath.

MMP-9 and MMP-2 appear to be central to the acute phases of ARDS; lung injury models demonstrate in- 
creases in their concentrations in BAL fluid following injury [104] (although this study did not report efforts to standardise the assay by measuring total protein content of different samples). This has been further supported by demonstration of increases following bleomycin injury in rats [105] and in a pig model of lung injury after cardiopulmonary bypass [106]. In human studies, the results have been more equivocal; one study demonstrated increased levels of MMP-2 and MMP-9, but at lower levels than a matched hospital-acquired pneumonia cohort [107]. On analysis of the ARDS group, those with a longer duration of illness had lower baseline MMP-9 levels, which may indicate a role in progression or persistence of inflammation. The mechanism underlying this role is not fully understood, as highlighted by a further observation from the BALTI study of $\beta_{2}$-agonists in ARDS, showing a trend to elevation of MMP-9 over the first 4 days of illness [108]. This may suggest a role in repair for this component of the ECM. Animal models highlight the complexity of the picture, of which our understanding remains incomplete. To take one example, MMP-9 knockout mice used in a variety of lung injury models give contradicting results $[109,110]$, suggesting a role both in exacerbation and mitigation of injury.

Targeting the ECM, and MMPs in particular, may be feasible in development of therapies for ARDS. A porcine LPS model of lung injury demonstrated that pre-treatment with COL-3, a non-specific MMP inhibitor, reduced histological injury and hypoxia compared with controls [111]. Repeated dosing of this inhibitor was associated with increased survival. Attenuation of injury was also seen in a rat caecal ligation/puncture model, pretreated with COL-3, where reduced lung water and improved histological grading for injury were observed [112].

The role of the ECM and MMPs in particular is complex; review of the role of this family in ARDS [28] concludes that their role in pathogenesis may be determined by the source of secretion, substrate availability at the site of activity and local ratios of active forms with any inhibitors present. A role that is further suggested in epithelial repair processes needs further investigation, with any role determining the trajectory of recovery or fibro-proliferation currently unclear.

\section{ACM Function (fig. 2, 4)}

Alveolar Fluid Clearance

The alveolar epithelium is, in health, a tight epithelium, restricting passive movement of solutes. Theories have been proposed for reabsorption of alveolar oede- ma; that it be driven by negative interstitial pressure, osmotic pressure differences or a transpulmonary airway pressure gradient. These have not been supported by data. Our understanding progressed when several investigators, working both in vivo and in vitro, demonstrated that excess interstitial fluid was cleared by a combination of lung lymphatics and bulk flow across the visceral pleura to the pleural space [113], driven by active transport of sodium into the interstitial space [114]. This is driven by $\mathrm{Na} / \mathrm{K}$-ATPase situated at the basolateral surface of the epithelial cell, generating a gradient to facilitate sodium entry at apical cell surface sodium channels.

In ARDS, this removal of pulmonary oedema is impaired, with reduced alveolar fluid clearance (AFC) correlating with higher mortality [115]. This reduced AFC can be induced by a variety of stimuli, including hypoxaemia and also elevated airway pressures [116], in part by inducing cell death and disrupting cell junctions. This is also exacerbated by IL- 8 , TGF- $\beta$ and IL- $1 \beta$, all of which decrease fluid transport by reducing $\mathrm{Na} / \mathrm{K}$-ATPase and $\mathrm{ENaC}$ expression $[69,117]$. There is also evidence that sepsis itself impairs AFC by down-regulating the $\mathrm{Na} / \mathrm{K}$ ATPase pump [118]. This may in part be due to mitochondrial dysfunction. One study demonstrated that low intracellular levels of ATP resulting from mitochondrial injury could be reversed through use of bone marrowderived mesenchymal stromal cells [119], suggesting that this may play a role in the apparent protective effects of this emergent therapy.

It is evident that mechanisms of AFC in ARDS are complex and multi-factorial, with contribution from hypoxia, hypercapnia, ventilator strategy, cytokines and pathogens. This makes targeting any single mechanism fraught with difficulty. The rationale that augmentation of the cAMP accelerated AFC mechanisms through $\beta_{2^{-}}$ adrenergic agonist stimulation in the BALTI trial was, unfortunately, unsuccessful [12].

\section{Loss of Integrity of the ACM}

A key impediment to restoring normal AFC mechanisms is loss of function and integrity of the ACM. This is in large part explained by death of type I and type II alveolar epithelial cells [120], along with endothelial cells. ARDS is associated with increased cell death in humans, while inhibitors of apoptosis promote increased survival in rodent models of lung injury [121]. Both intrinsic and extrinsic apoptosis pathways have been implicated, with increased Fas/FasL in ARDS patients compared to controls, but also induction of apoptosis through ventilator- 


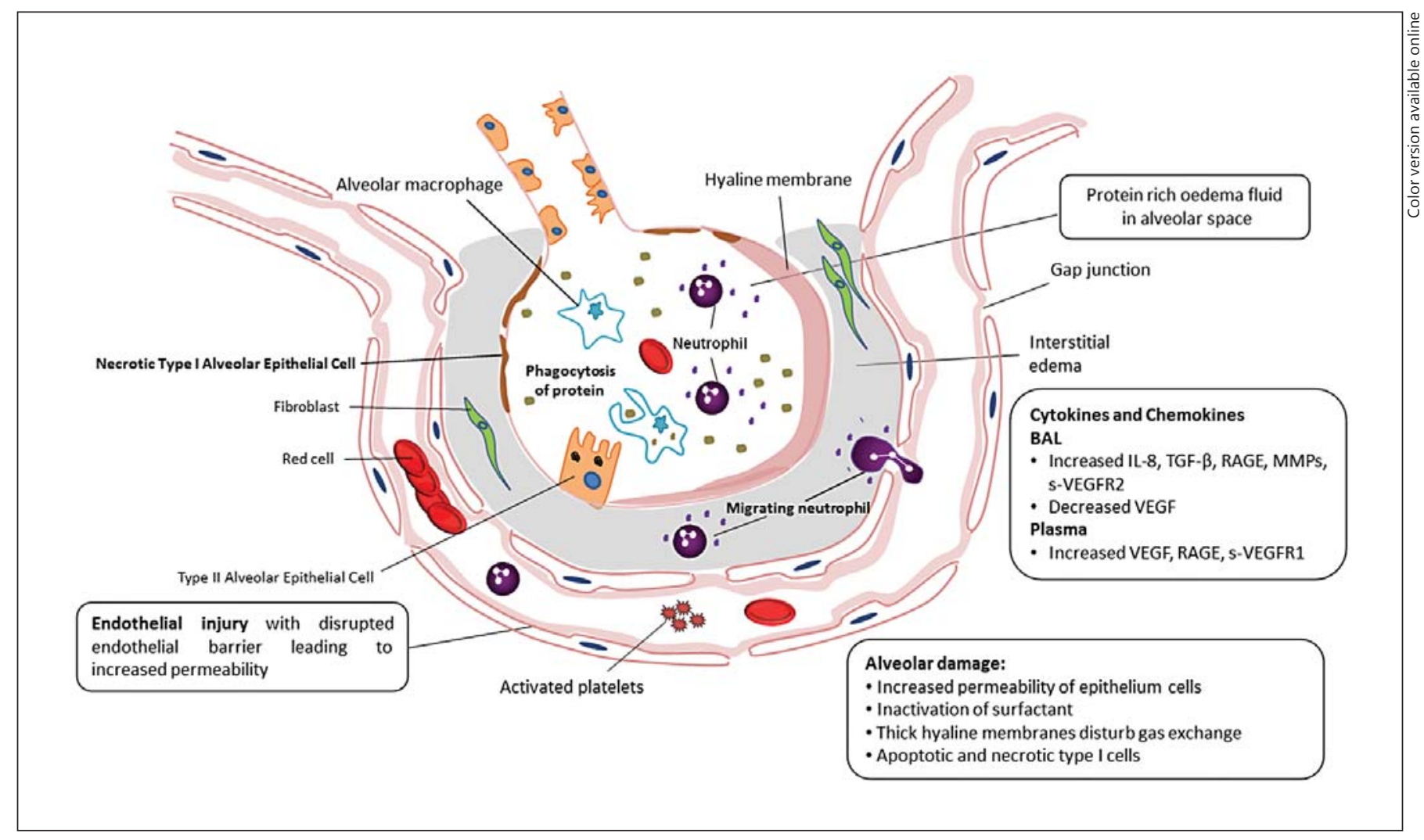

Fig. 4. Exudative phase of ARDS.

induced mechanical stress, hypoxia, oxidative stress and inducible NO synthase generated NO [122]. Neutrophilic inflammation is probably a key component of this increase in cell death, through action of ROS derived from $\mathrm{NADPH}$ oxidase 1 and mediated through the STAT3 (signal transducer and activator of transcription 3) signalling pathway [123]. Epithelial cell death can be manipulated through use of survivin, an inhibitor of apoptosis. A study combining a mouse model of lung injury and in vitro culture of human alveolar epithelial cells demonstrated a protective effect through reduction in apoptosis-related molecules [124].

Thus, a better understanding of the mechanisms of this cell death and the regeneration of the injured epithelium is central to generation of effective treatments.

\section{Microvascular Permeability}

As discussed above, reduced AFC plays a role in the pathogenesis of ARDS. In addition to this, an increase in microvascular permeability is a cardinal feature of acute inflammation in general, and ARDS in particular. This results in increased levels of leukocytes, erythrocytes and inflammatory cytokines [125]. There are a variety of mechanisms underlying this at the level of both endothelium and epithelium.

Disruption of vascular endothelial-cadherin bonds destabilises endothelial barrier function; this can result from a number of mediators discussed above, including VEGF and leukocyte signals, contributing to alveolar oedema [126]. Stabilisation of these bonds has been explored as a possible therapeutic target, with sphingosine1-phosphate representing one possible avenue [127]. In addition, extracellular ATP and platelet-derived nucleotides may enhance endothelial permeability [128]. The mitochondrial damage-associated molecular patterns which appear after injury or shock in blood and activate neutrophils have also been shown to increase endothelial permeability through both neutrophil-dependent and -independent pathways [129]. The neutrophilic contribution to endothelial barrier compromise is supported by a study showing increased permeability of cultured endothelial cells when exposed to neutrophils purified from ARDS patients, as compared to those derived from healthy controls [128]. 
Fig. 5. Resolution of lung injury.

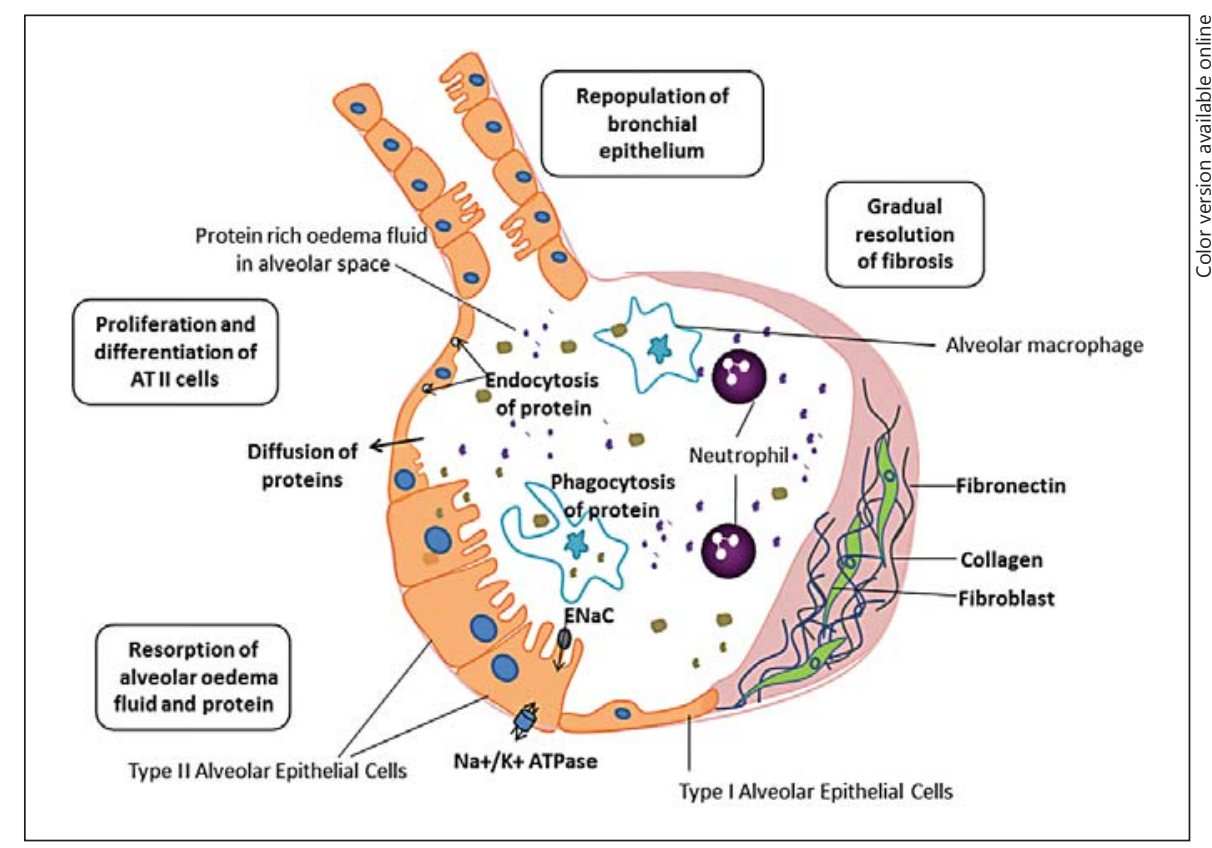

Table 3. Ongoing trials in ARDS

\begin{tabular}{llll}
\hline Intervention & $\begin{array}{l}\text { Estimated } \\
\text { enrolment }\end{array}$ & $\begin{array}{l}\text { Expected } \\
\text { completion }\end{array}$ & $\begin{array}{l}\text { Clinicaltrials.gov } \\
\text { reference }\end{array}$ \\
\hline ECMO & 331 & January 2016 & NCT01470703 \\
Hydrocortisone & 196 & December 2014 & NCT01284452 \\
Dexamethasone & 314 & December 2015 & NCT01731795 \\
Human mesenchymal stem cells & 69 & February 2017 & NCT01775774 \\
Perfluorocarbon & 200 & April 2015 & NCT01391481 \\
\hline
\end{tabular}

$\mathrm{ECMO}=$ Extracorporeal membrane oxygenation.

Mechanical Stretch

ARDS results almost uniformly in a need for mechanical ventilation. While the ARDSnet studies created a dramatic change in ventilator strategy, the heterogeneity of ventilation in patients with the reduced compliance and pulmonary inflammation seen in ARDS still leads to the risk of ventilator-induced exacerbation of injury.

The cyclical stretch of alveolar epithelial cells has been recognised to change gene expression patterns [130] and modulate the response to inflammatory mediators. Mechanical ventilation has itself been shown to induce inflammatory mediator release from epithelial cells and promote epithelial-mesenchymal transformation [131, 132].

This interplay of iatrogenic induction of changes in epithelial cell expression patterns, superimposed on the existing complexity of the ARDS pathogenetic process increases the difficulties in identifying targets for therapeutic approaches. It also highlights the vital role the ongoing efforts to optimise ventilator strategy, including prone ventilation and extracorporeal membrane oxygenation, play in improving care in ARDS.

\section{Mechanisms of Repair (fig. 5)}

The restoration of the lung to normal function is a complicated and incompletely understood phenomenon. The removal of protein-rich alveolar oedema, clearance of neutrophils and debris and repair of the barrier properties of the ACM are all prerequisites. The mechanisms underlying this are poorly understood, with difficulty generating appropriate and accurate models of this phase of ARDS [133]. 
One area currently drawing significant attention is the role of progenitor cells in this process. The paradigm has previously been that AT2 cells are the source of new AT1 cells; however, there is evidence that a separate cell population, with distinct cell surface markers and lacking surfactant protein $\mathrm{C}$ expression, may be pluripotential for differentiation to either AT1 or AT2 cells [134]. This has led to studies exploring the therapeutic potential of stem cell therapies in ARDS, which have rapidly reached clinical trials $[135,136]$. This area is beyond the scope of this review.

\section{Translation to Patient Benefit}

We have highlighted above developments in our mechanistic understanding of ARDS. Direct developments from such investigations have been limited; table 1 shows that the majority of clinical trials of therapeutic agents have been negative and in fact several have demonstrated increased mortality. This underscores the fact that ARDS is a complex, multi-factorial process. No single molecule described above acts in isolation, making the development of targeted therapies fraught with difficulty.

There are, nevertheless, several ongoing trials further investigating both treatments previously considered and novel approaches to clarify their role in management of ARDS. These are summarised in table 3.

The route to patient benefit in this area will remain long and difficult, however, and research strategy may benefit from a focus on the balance and inter-relation between those molecules identified as being of interest. It is likely to be this balance between different forces which holds the key to both the disproportionate inflammation in ARDS and the heterogeneity in tissue repair and resolution from lung injury.

\section{Conclusions}

There has been a rapid increase in our understanding of the pathogenetic mechanisms underlying ARDS over the last 5-10 years, which has served to highlight areas requiring further study and possible therapeutic targets. It is increasingly apparent that the complexity of this syndrome represents a multitude of different mechanisms, and phenotypic characterisation of different subsets of patients is likely to be necessary in order to better target treatments which may be developed in the future.

While some clinical studies are in progress, there remain no disease-modifying treatments for ARDS, and supportive care with appropriate ventilatory strategies remains the mainstay of care for these patients.

\section{Disclosure Statement}

The authors have no conflicts of interest to declare.

\section{References}

1 Ashbaugh DG, Bigelow DB, Petty TL, Levine BE: Acute respiratory distress in adults. Lancet 1967;2:319-323.

2 Sloggett A: Memorandum of the Treatment of Injuries in War. London, Harrison and Sons, 1915, pp 115-122.

-3 Rubenfeld GD, Caldwell E, Peabody E, Weaver J, Martin DP, Neff M, et al: Incidence and outcomes of acute lung injury. N Engl J Med 2005; 353:1685-1693.

4 Orme J, Romney JS, Hopkins RO, Pope D, Chan KJ, Thomsen G, et al: Pulmonary function and health-related quality of life in survivors of acute respiratory distress syndrome. Am J Respir Crit Care Med 2003;167:690-694.

5 Herridge MS, Tansey CM, Matté A, Tomlinson G, Diaz-Granados N, Cooper A, et al: Functional disability 5 years after acute respiratory distress syndrome. N Engl J Med 2011;364: 1293-1304.
6 Ventilation with lower tidal volumes as compared with traditional tidal volumes for acute lung injury and the acute respiratory distress syndrome. The Acute Respiratory Distress Syndrome Network. N Engl J Med 2000;342:13011308.

7 Brower RG, Lanken PN, MacIntyre N, Matthay MA, Morris A, Ancukiewicz M, et al: Higher versus lower positive end-expiratory pressures in patients with the acute respiratory distress syndrome. N Engl J Med 2004; 351:327-336.

8 Taylor RW, Zimmerman JL, Dellinger RP, Straube RC, Criner GJ, Davis K, et al: Low-dose inhaled nitric oxide in patients with acute lung injury: a randomized controlled trial. JAMA 2004;291:1603-1609.

-9 Bernard GR, Luce JM, Sprung CL, Rinaldo JE, Tate RM, Sibbald WJ, et al: High-dose corticosteroids in patients with the adult respiratory distress syndrome. N Engl J Med 1987;317: 1565-1570.
10 Meduri GU, Golden E, Freire AX, Taylor E, Zaman M, Carson SJ, et al: Methylprednisolone infusion in early severe ARDS: results of a randomized controlled trial. Chest 2007;131:954963.

11 Guerin C, Reignier J, Richard JC, Beuret P, Gacouin A, Boulain T, et al: Prone positioning in severe acute respiratory distress syndrome. N Engl J Med 2013;368:2159-2168.

12 Gao Smith F, Perkins GD, Gates S, Young D, McAuley DF, Tunnicliffe W, et al: Effect of intravenous $\beta$-2 agonist treatment on clinical outcomes in acute respiratory distress syndrome (BALTI-2): a multicentre, randomised controlled trial. Lancet 2012;379:229-235.

-13 Ferguson ND, Cook DJ, Guyatt GH, Mehta S, Hand L, Austin P, et al: High-frequency oscillation in early acute respiratory distress syndrome. N Engl J Med 2013;368:795-805. 
${ }_{14}$ Young D, Lamb SE, Shah S, MacKenzie I, Tunnicliffe W, Lall R, et al: High-frequency oscillation for acute respiratory distress syndrome. $\mathrm{N}$ Engl J Med 2013;368:806-813.

-15 Peek GJ, Mugford M, Tiruvoipati R, Wilson A, Allen E, Thalanany MM, et al: Efficacy and economic assessment of conventional ventilatory support versus extracorporeal membrane oxygenation for severe adult respiratory failure (CESAR): a multicentre randomised controlled trial. Lancet 2009;374:1351-1363.

>16 McAuley DF, Laffey JG, O’Kane CM, Perkins GD, Mullan B, Trinder TJ, et al: Simvastatin in the acute respiratory distress syndrome. $\mathrm{N}$ Engl J Med 2014;371:1695-1703.

- 17 Zeiher BG, Artigas A, Vincent JL, Dmitrienko A, Jackson K, Thompson BT, et al: Neutrophil elastase inhibition in acute lung injury: results of the STRIVE study. Crit Care Med 2004;32: 1695-1702.

- 18 Bernard GR, Artigas A, Brigham KL, Carlet J, Falke K, Hudson L, et al: The American-European Consensus Conference on ARDS. Definitions, mechanisms, relevant outcomes, and clinical trial coordination. Am J Respir Crit Care Med 1994;149:818-824.

19 Ranieri VM, Rubenfeld GD, Thompson BT, Ferguson ND, Caldwell E, Fan E, et al: Acute respiratory distress syndrome: the Berlin Definition. JAMA 2012;307:2526-2533.

-20 Hernu R, Wallet F, Thiollière F, Martin O, Richard JC, Schmitt Z, et al: An attempt to validate the modification of the American-European consensus definition of acute lung injury/ acute respiratory distress syndrome by the Berlin definition in a university hospital. Intensive Care Med 2013;39:2161-2170.

21 Ware LB, Matthay MA: The acute respiratory distress syndrome. N Engl J Med 2000;342: 1334-1349.

-22 Thille AW, Esteban A, Fernandez-Segoviano P, Rodriguez JM, Aramburu JA, Vargas-Errazuriz $\mathrm{P}$, et al: Chronology of histological lesions in acute respiratory distress syndrome with diffuse alveolar damage: a prospective cohort study of clinical autopsies. Lancet Respir Med 2013;1:395-401.

-23 Matute-Bello G, Frevert CW, Martin TR: Animal models of acute lung injury. Am J Physiol Lung Cell Mol Physiol 2008;295:L379-L399.

24 Medford A, Millar A: Tolerability of bronchoalveolar lavage in ventilated patients with acute lung injury. Glob J Respir Care 2014;1:9-12.

-25 Medford AR, Husain SA, Turki HM, Millar AB: Diagnosis of ventilator-associated pneumonia. J Crit Care 2009;24:473.e1-e6.

-26 Grommes J, Soehnlein O: Contribution of neutrophils to acute lung injury. Mol Med 2011;17: 293-307.

-27 Armstrong L, Medford AR, Uppington KM, Robertson J, Witherden IR, Tetley TD, et al: Expression of functional toll-like receptor- 2 and -4 on alveolar epithelial cells. Am J Respir Cell Mol Biol 2004;31:241-245.

28 Davey A, McAuley DF, O’Kane CM: Matrix metalloproteinases in acute lung injury: mediators of injury and drivers of repair. Eur Respir J 2011;38:959-970.
29 Ferrara N: Molecular and biological properties of vascular endothelial growth factor. J Mol Med (Berl) 1999;77:527-543.

-30 Thickett DR, Armstrong L, Christie SJ, Millar AB: Vascular endothelial growth factor may contribute to increased vascular permeability in acute respiratory distress syndrome. Am J Respir Crit Care Med 2001;164:1601-1605.

31 Hanaoka M, Droma Y, Naramoto A, Honda T, Kobayashi T, Kubo K: Vascular endothelial growth factor in patients with high-altitude pulmonary edema. J Appl Physiol (1985) 2003; 94:1836-1840.

32 Medford AR, Keen LJ, Bidwell JL, Millar AB: Vascular endothelial growth factor gene polymorphism and acute respiratory distress syndrome. Thorax 2005;60:244-248.

33 Medford AR, Godinho SI, Keen LJ, Bidwell JL, Millar AB: Relationship between vascular endothelial growth factor +936 genotype and plasma/epithelial lining fluid vascular endothelial growth factor protein levels in patients with and at risk for ARDS. Chest 2009;136:457-464.

34 Thickett DR, Armstrong L, Millar AB: A role for vascular endothelial growth factor in acute and resolving lung injury. Am J Respir Crit Care Med 2002;166:1332-1337.

35 Dvorak HF, Brown LF, Detmar M, Dvorak AM: Vascular permeability factor/vascular endothelial growth factor, microvascular hyperpermeability, and angiogenesis. Am J Pathol 1995;146:1029-1039.

36 Kaner RJ, Crystal RG: Compartmentalization of vascular endothelial growth factor to the epithelial surface of the human lung. Mol Med 2001;7:240-246.

37 Barratt S, Medford AR, Millar AB: Vascular endothelial growth factor in acute lung injury and acute respiratory distress syndrome. Respiration 2014;87:329-342.

38 Medford AR, Millar AB: Vascular endothelial growth factor (VEGF) in acute lung injury (ALI) and acute respiratory distress syndrome (ARDS): paradox or paradigm? Thorax 2006; 61:621-626.

39 Ferrara N, Gerber HP, LeCouter J: The biology of VEGF and its receptors. Nat Med 2003;9: 669-676.

40 Tischer E, Mitchell R, Hartman T, Silva M, Gospodarowicz D, Fiddes JC, et al: The human gene for vascular endothelial growth factor. Multiple protein forms are encoded through alternative exon splicing. J Biol Chem 1991;266: 11947-11954.

41 Robinson CJ, Stringer SE: The splice variants of vascular endothelial growth factor (VEGF) and their receptors. J Cell Sci 2001;114:853-865.

-42 Wada T, Jesmin S, Gando S, Yanagida Y, Mizugaki A, Sultana SN, et al: The role of angiogenic factors and their soluble receptors in acute lung injury (ALI)/acute respiratory distress syndrome (ARDS) associated with critical illness. J Inflamm (Lond) 2013;10:6.

43 Medford AR, Ibrahim NB, Millar AB: Vascular endothelial growth factor receptor and coreceptor expression in human acute respiratory distress syndrome. J Crit Care 2009;24:236242.
44 Perkins GD, Roberts J, McAuley DF, Armstrong L, Millar A, Gao F, et al: Regulation of vascular endothelial growth factor bioactivity in patients with acute lung injury. Thorax 2005; 60:153-158

45 Medford AR, Douglas SK, Godinho SI, Uppington KM, Armstrong L, Gillespie KM, et al: Vascular endothelial growth factor (VEGF) isoform expression and activity in human and murine lung injury. Respir Res 2009;10:27.

46 Bates DO, Cui TG, Doughty JM, Winkler M, Sugiono M, Shields JD, et al: VEGF165b, an inhibitory splice variant of vascular endothelial growth factor, is down-regulated in renal cell carcinoma. Cancer Res 2002;62:41234131.

47 Harper SJ, Bates DO: VEGF-A splicing: the key to anti-angiogenic therapeutics? Nat Rev Cancer 2008;8:880-887.

48 Eswarappa SM, Potdar AA, Koch WJ, Fan Y, Vasu K, Lindner D, et al: Programmed translational readthrough generates antiangiogenic VEGF-Ax. Cell 2014;157:1605-1618.

49 Varet J, Douglas SK, Gilmartin L, Medford AR, Bates DO, Harper SJ, et al: VEGF in the lung: a role for novel isoforms. Am J Physiol Lung Cell Mol Physiol 2010;298:L768-L774.

50 Piednoir P, Quesnel C, Nardelli L, Leçon V, Bouadma L, Lasocki S, et al: Alveolar fluid in acute respiratory distress syndrome promotes fibroblast migration: role of platelet-derived growth factor pathway. Crit Care Med 2012;40: 2041-2049.

51 Borensztajn K, Crestani B, Kolb M: Idiopathic pulmonary fibrosis: from epithelial injury to biomarkers - insights from the bench side. Respiration 2013;86:441-452.

52 Richeldi L, du Bois RM, Raghu G, Azuma A, Brown KK, Costabel U, et al: Efficacy and safety of nintedanib in idiopathic pulmonary fibrosis. N Engl J Med 2014;370:2071-2082.

53 Rhee CK, Lee SH, Yoon HK, Kim SC, Lee SY, Kwon SS, et al: Effect of nilotinib on bleomycin-induced acute lung injury and pulmonary fibrosis in mice. Respiration 2011;82:273287.

54 Miller EJ, Cohen AB, Nagao S, Griffith D, Maunder RJ, Martin TR, et al: Elevated levels of NAP-1/interleukin- 8 are present in the airspaces of patients with the adult respiratory distress syndrome and are associated with increased mortality. Am Rev Respir Dis 1992;146:427432.

55 Ware LB, Koyama T, Zhao Z, Janz DR, Wickersham N, Bernard GR, et al: Biomarkers of lung epithelial injury and inflammation distinguish severe sepsis patients with acute respiratory distress syndrome. Crit Care 2013;17:R253.

56 Allen TC, Kurdowska A: Interleukin 8 and acute lung injury. Arch Pathol Lab Med 2014; 138:266-269.

57 Kurdowska A, Miller EJ, Noble JM, Baughman RP, Matthay MA, Brelsford WG, et al: Anti-IL-8 autoantibodies in alveolar fluid from patients with the adult respiratory distress syndrome. J Immunol 1996;157:26992706. 
58 Krupa A, Kato H, Matthay MA, Kurdowska AK: Proinflammatory activity of anti-IL-8 autoantibody: IL-8 complexes in alveolar edema fluid from patients with acute lung injury. Am J Physiol Lung Cell Mol Physiol 2004;286: L1105-L1113.

-59 Agrawal A, Zhuo H, Brady S, Levitt J, Steingrub J, Siegel MD, et al: Pathogenetic and predictive value of biomarkers in patients with ALI and lower severity of illness: results from two clinical trials. Am J Physiol Lung Cell Mol Physiol 2012;303:L634-L639.

60 Ahuja SK, Lee JC, Murphy PM: CXC chemokines bind to unique sets of selectivity determinants that can function independently and are broadly distributed on multiple domains of human interleukin-8 receptor B. Determinants of high affinity binding and receptor activation are distinct. J Biol Chem 1996;271:225-232.

-61 Belperio JA, Keane MP, Burdick MD, Gomperts BN, Xue YY, Hong K, et al: CXCR2/ CXCR2 ligand biology during lung transplant ischemia-reperfusion injury. J Immunol 2005 175:6931-6939.

-62 Sue RD, Belperio JA, Burdick MD, Murray LA, Xue YY, Dy MC, et al: CXCR2 is critical to hyperoxia-induced lung injury. J Immunol 2004; 172:3860-3868.

63 Chapman RW, Minnicozzi M, Celly CS, Phillips JE, Kung TT, Hipkin RW, et al: A novel, orally active CXCR1/2 receptor antagonist, Sch527123, inhibits neutrophil recruitment, mucus production, and goblet cell hyperplasia in animal models of pulmonary inflammation. J Pharmacol Exp Ther 2007;322:486-493.

64 Jenkins RG, Su X, Su G, Scotton CJ, Camerer E, Laurent GJ, et al: Ligation of protease-activated receptor 1 enhances $\alpha_{v} \beta_{6}$ integrin-dependent TGF- $\beta$ activation and promotes acute lung injury. J Clin Invest 2006;116:1606-1614.

-65 Budinger GR, Chandel NS, Donnelly HK, Eisenbart J, Oberoi M, Jain M: Active transforming growth factor-betal activates the procollagen I promoter in patients with acute lung injury. Intensive Care Med 2005;31:121-128.

- 66 Akbarshahi H, Sam A, Chen C, Rosendahl AH, Andersson R: Early activation of pulmonary TGF- $\beta 1 /$ Smad 2 signaling in mice with acute pancreatitis-associated acute lung injury. $\mathrm{Me}$ diators Inflamm 2014;2014:148029.

67 Frank J, Roux J, Kawakatsu H, Su G, Dagenais A, Berthiaume Y, et al: Transforming growth factor- $\beta 1$ decreases expression of the epithelial sodium channel $\alpha \mathrm{ENaC}$ and alveolar epithelial vectorial sodium and fluid transport via an ERK1/2-dependent mechanism. J Biol Chem 2003;278:43939-43950.

-68 Willis BC, Kim KJ, Li X, Liebler J, Crandall ED, Borok Z: Modulation of ion conductance and active transport by TGF-beta 1 in alveolar epithelial cell monolayers. Am J Physiol Lung Cell Mol Physiol 2003;285:L1192-L1200.

-69 Pittet JF, Griffiths MJ, Geiser T, Kaminski N, Dalton SL, Huang X, et al: TGF-beta is a critical mediator of acute lung injury. J Clin Invest 2001;107:1537-1544.

-70 Peters DM, Vadász I, Wujak L, Wygrecka M, Olschewski A, Becker C, et al: TGF- $\beta$ directs trafficking of the epithelial sodium channel
$\mathrm{ENaC}$ which has implications for ion and fluid transport in acute lung injury. Proc Natl Acad Sci USA 2014;111:E374-E383.

71 Ribeiro SM, Poczatek M, Schultz-Cherry S, Villain M, Murphy-Ullrich JE: The activation sequence of thrombospondin-1 interacts with the latency-associated peptide to regulate activation of latent transforming growth factor-beta. J Biol Chem 1999;274:13586-13593.

72 Wakefield LM, Winokur TS, Hollands RS, Christopherson K, Levinson AD, Sporn MB: Recombinant latent transforming growth factor beta 1 has a longer plasma half-life in rats than active transforming growth factor beta 1 , and a different tissue distribution. J Clin Invest 1990;86:1976-1984.

73 Tran DQ, Andersson J, Wang R, Ramsey H, Unutmaz D, Shevach EM: GARP (LRRC32) is essential for the surface expression of latent TGF-beta on platelets and activated FOXP3+ regulatory T cells. Proc Natl Acad Sci USA 2009;106:13445-13450.

74 Böttinger EP, Factor VM, Tsang ML, Weatherbee JA, Kopp JB, Qian SW, et al: The recombinant proregion of transforming growth factor betal (latency-associated peptide) inhibits active transforming growth factor betal in transgenic mice. Proc Natl Acad Sci USA 1996;93: 5877-5882.

75 Tang YJ, Xiao J, Huang XR, Zhang Y, Yang C, Meng XM, et al: Latent transforming growth factor-betal protects against bleomycin-induced lung injury in mice. Am J Respir Cell Mol Biol 2014;51:761-771.

76 Frank JA, Matthay MA: TGF- $\beta$ and lung fluid balance in ARDS. Proc Natl Acad Sci USA 2014;111:885-886.

77 Synenki L, Chandel NS, Budinger GR, Donnelly HK, Topin J, Eisenbart J, et al: Bronchoalveolar lavage fluid from patients with acute lung injury/acute respiratory distress syndrome induces myofibroblast differentiation. Crit Care Med 2007;35:842-848.

78 Fernandez IE, Eickelberg O: The impact of TGF-beta on lung fibrosis: from targeting to biomarkers. Proc Am Thorac Soc 2012;9:111116.

79 Uchida T, Shirasawa M, Ware LB, Kojima K, Hata Y, Makita K, et al: Receptor for advanced glycation end-products is a marker of type I cell injury in acute lung injury. Am J Respir Crit Care Med 2006;173:1008-1015.

80 Schmidt AM, Yan SD, Yan SF, Stern DM: The multiligand receptor RAGE as a progression factor amplifying immune and inflammatory responses. J Clin Invest 2001;108:949-955.

81 Bierhaus A, Humpert PM, Morcos M, Wendt T, Chavakis T, Arnold B, et al: Understanding RAGE, the receptor for advanced glycation end products. J Mol Med (Berl) 2005;83:876-886.

82 Calfee CS, Ware LB, Eisner MD, Parsons PE, Thompson BT, Wickersham N, et al: Plasma receptor for advanced glycation end products and clinical outcomes in acute lung injury. Thorax 2008;63:1083-1089.

83 Nakamura T, Sato E, Fujiwara N, Kawagoe Y, Maeda S, Yamagishi S: Increased levels of soluble receptor for advanced glycation end products (sRAGE) and high mobility group box 1
(HMGB1) are associated with death in patients with acute respiratory distress syndrome. Clin Biochem 2011;44:601-604

84 Laffon M, Pittet JF, Modelska K, Matthay MA, Young DM: Interleukin-8 mediates injury from smoke inhalation to both the lung endothelial and the alveolar epithelial barriers in rabbits. Am J Respir Crit Care Med 1999;160:14431449.

85 Bao Z, Ye Q, Gong W, Xiang Y, Wan H: Humanized monoclonal antibody against the chemokine CXCL-8 (IL-8) effectively prevents acute lung injury. Int Immunopharmacol 2010; 10:259-263.

- 86 Osman MO, Kristensen JU, Jacobsen NO, Lausten SB, Deleuran B, Deleuran M, et al: A monoclonal anti-interleukin 8 antibody (WS4) inhibits cytokine response and acute lung injury in experimental severe acute necrotising pancreatitis in rabbits. Gut 1998;43:232239.

87 Folkesson HG, Matthay MA, Hébert CA, Broaddus VC: Acid aspiration-induced lung injury in rabbits is mediated by interleukin-8-dependent mechanisms. J Clin Invest 1995;96:107116.

88 Sharma AK, LaPar DJ, Zhao Y, Li L, Lau CL, Kron IL, et al: Natural killer T cell-derived IL-17 mediates lung ischemia-reperfusion injury. Am J Respir Crit Care Med 2011;183:15391549.

89 Hudock KM, Liu Y, Mei J, Marino RC, Hale JE, Dai N, et al: Delayed resolution of lung inflammation in Il-1 $1 \mathrm{rn}^{-/-}$mice reflects elevated IL$17 \mathrm{~A} /$ granulocyte colony-stimulating factor expression. Am J Respir Cell Mol Biol 2012;47: 436-444.

90 Ognibene FP, Martin SE, Parker MM, Schlesinger T, Roach P, Burch C, et al: Adult respiratory distress syndrome in patients with severe neutropenia. N Engl J Med 1986;315: 547-551.

91 Brinkmann V, Reichard U, Goosmann C, Fauler B, Uhlemann Y, Weiss DS, et al: Neutrophil extracellular traps kill bacteria. Science 2004; 303:1532-1535.

92 Narasaraju T, Yang E, Samy RP, Ng HH, Poh WP, Liew AA, et al: Excessive neutrophils and neutrophil extracellular traps contribute to acute lung injury of influenza pneumonitis. Am J Pathol 2011;179:199-210.

93 Ichikawa A, Kuba K, Morita M, Chida S, Tezuka $\mathrm{H}$, Hara $\mathrm{H}$, et al: CXCL10-CXCR3 enhances the development of neutrophil-mediated fulminant lung injury of viral and nonviral origin. Am J Respir Crit Care Med 2013;187: 65-77.

94 Summers C, Singh NR, White JF, Mackenzie IM, Johnston A, Solanki C, et al: Pulmonary retention of primed neutrophils: a novel protective host response, which is impaired in the acute respiratory distress syndrome. Thorax 2014;69:623-629.

95 Shah D, Romero F, Stafstrom W, Duong M, Summer R: Extracellular ATP mediates the late phase of neutrophil recruitment to the lung in murine models of acute lung injury. Am J Physiol Lung Cell Mol Physiol 2014;306:L152L161. 
D6 Soehnlein O, Oehmcke S, Ma X, Rothfuchs AG, Frithiof R, van Rooijen N, et al: Neutrophil degranulation mediates severe lung damage triggered by streptococcal M1 protein. Eur Respir J 2008;32:405-412.

-97 Donnelly SC, MacGregor I, Zamani A, Gordon MW, Robertson CE, Steedman DJ, et al: Plasma elastase levels and the development of the adult respiratory distress syndrome. Am J Respir Crit Care Med 1995;151:1428-1433.

-98 Fujii M, Miyagi Y, Bessho R, Nitta T, Ochi M, Shimizu K: Effect of a neutrophil elastase inhibitor on acute lung injury after cardiopulmonary bypass. Interact Cardiovasc Thorac Surg 2010;10:859-862.

$>99$ Delacourt C, Hérigault S, Delclaux C, Poncin A, Levame M, Harf A, et al: Protection against acute lung injury by intravenous or intratracheal pretreatment with EPI-HNE-4, a new potent neutrophil elastase inhibitor. Am J Respir Cell Mol Biol 2002;26:290-297.

-100 Sugamata R, Dobashi H, Nagao T, Yamamoto K, Nakajima N, Sato Y, et al: Contribution of neutrophil-derived myeloperoxidase in the early phase of fulminant acute respiratory distress syndrome induced by influenza virus infection. Microbiol Immunol 2012;56:171182.

101 Auten RL, Whorton MH, Nicholas Mason S: Blocking neutrophil influx reduces DNA damage in hyperoxia-exposed newborn rat lung. Am J Respir Cell Mol Biol 2002;26:391397.

102 Dunsmore SE, Rannels DE: Extracellular matrix biology in the lung. Am J Physiol 1996; 270:L3-L27.

103 Greenlee KJ, Werb Z, Kheradmand F: Matrix metalloproteinases in lung: multiple, multifarious, and multifaceted. Physiol Rev 2007; 87:69-98.

104 Gushima Y, Ichikado K, Suga M, Okamoto T, Iyonaga K, Sato K, et al: Expression of matrix metalloproteinases in pigs with hyperoxia-induced acute lung injury. Eur Respir J 2001;18: 827-837.

$>105$ Kim JY, Choeng HC, Ahn C, Cho SH: Early and late changes of MMP-2 and MMP-9 in bleomycin-induced pulmonary fibrosis. Yonsei Med J 2009;50:68-77.

106 Eichler W, Bechtel JF, Schumacher J, Wermelt JA, Klotz KF, Bartels C: A rise of MMP-2 and MMP-9 in bronchoalveolar lavage fluid is associated with acute lung injury after cardiopulmonary bypass in a swine model. Perfusion 2003; 18:107-113.

-107 Lanchou J, Corbel M, Tanguy M, Germain N, Boichot E, Theret N, et al: Imbalance between matrix metalloproteinases (MMP-9 and MMP-2) and tissue inhibitors of metalloproteinases (TIMP-1 and TIMP-2) in acute respiratory distress syndrome patients. Crit Care Med 2003;31:536-542.

-108 O’Kane CM, McKeown SW, Perkins GD, Bassford CR, Gao F, Thickett DR, et al: Salbutamol up-regulates matrix metalloproteinase- 9 in the alveolar space in the acute respiratory distress syndrome. Crit Care Med 2009; 37:2242-2249.
109 Lukkarinen H, Hogmalm A, Lappalainen U, Bry K: Matrix metalloproteinase-9 deficiency worsens lung injury in a model of bronchopulmonary dysplasia. Am J Respir Cell Mol Biol 2009;41:59-68.

110 Warner RL, Beltran L, Younkin EM, Lewis CS, Weiss SJ, Varani J, et al: Role of stromelysin 1 and gelatinase $B$ in experimental acute lung injury. Am J Respir Cell Mol Biol 2001; 24:537-544.

111 Carney DE, McCann UG, Schiller HJ, Gatto LA, Steinberg J, Picone AL, et al: Metalloproteinase inhibition prevents acute respiratory distress syndrome. J Surg Res 2001;99:245252.

112 Steinberg J, Halter J, Schiller HJ, Dasilva M, Landas S, Gatto LA, et al: Metalloproteinase inhibition reduces lung injury and improves survival after cecal ligation and puncture in rats. J Surg Res 2003;111:185-195.

113 Wiener-Kronish JP, Broaddus VC, Albertine KH, Gropper MA, Matthay MA, Staub NC: Relationship of pleural effusions to increased permeability pulmonary edema in anesthetized sheep. J Clin Invest 1988;82: 1422-1429.

114 Matthay MA, Folkesson HG, Clerici C: Lung epithelial fluid transport and the resolution of pulmonary edema. Physiol Rev 2002;82:569600.

115 Ware LB, Matthay MA: Alveolar fluid clearance is impaired in the majority of patients with acute lung injury and the acute respiratory distress syndrome. Am J Respir Crit Care Med 2001;163:1376-1383.

116 Matthay MA: Resolution of pulmonary edema. Thirty years of progress. Am J Respir Crit Care Med 2014;189:1301-1308.

117 Roux J, McNicholas CM, Carles M, Goolaerts A, Houseman BT, Dickinson DA, et al: IL-8 inhibits CAMP-stimulated alveolar epithelial fluid transport via a GRK2/PI3K-dependent mechanism. FASEB J 2013;27:1095-1106.

$>118$ Berger G, Guetta J, Klorin G, Badarneh R, Braun E, Brod V, et al: Sepsis impairs alveolar epithelial function by downregulating $\mathrm{Na}-\mathrm{K}$ ATPase pump. Am J Physiol Lung Cell Mol Physiol 2011;301:L23-L30.

119 Islam MN, Das SR, Emin MT, Wei M, Sun L, Westphalen K, et al: Mitochondrial transfer from bone-marrow-derived stromal cells to pulmonary alveoli protects against acute lung injury. Nat Med 2012;18:759-765.

120 Galani V, Tatsaki E, Bai M, Kitsoulis P, Lekka M, Nakos G, et al: The role of apoptosis in the pathophysiology of Acute Respiratory Distress Syndrome (ARDS): an up-to-date cellspecific review. Pathol Res Pract 2010;206: 145-150.

-121 Rudkowski JC, Barreiro E, Harfouche R, Goldberg P, Kishta O, D'Orleans-Juste P, et al: Roles of iNOS and nNOS in sepsis-induced pulmonary apoptosis. Am J Physiol Lung Cell Mol Physiol 2004;286:L793-L800.

122 Lucas R, Verin AD, Black SM, Catravas JD: Regulators of endothelial and epithelial barrier integrity and function in acute lung injury. Biochem Pharmacol 2009;77:1763-1772.
123 Carnesecchi S, Dunand-Sauthier I, Zanetti F, Singovski G, Deffert C, Donati Y, et al: NOX1 is responsible for cell death through STAT3 activation in hyperoxia and is associated with the pathogenesis of acute respiratory distress syndrome. Int J Clin Exp Pathol 2014;7:537551.

124 Terasaki Y, Terasaki M, Urushiyama H, Nagasaka S, Takahashi M, Kunugi S, et al: Role of survivin in acute lung injury: epithelial cells of mice and humans. Lab Invest 2013;93:11471163.

125 Matthay MA, Ware LB, Zimmerman GA: The acute respiratory distress syndrome. J Clin Invest 2012;122:2731-2740.

126 Vestweber D, Winderlich M, Cagna G, Nottebaum AF: Cell adhesion dynamics at endothelial junctions: VE-cadherin as a major player. Trends Cell Biol 2009;19:8-15.

127 Obinata H, Hla T: Sphingosine 1-phosphate in coagulation and inflammation. Semin Immunopathol 2012;34:73-91.

128 Fox ED, Heffernan DS, Cioffi WG, Reichner JS: Neutrophils from critically ill septic patients mediate profound loss of endothelial barrier integrity. Crit Care 2013;17:R226.

129 Sun S, Sursal T, Adibnia Y, Zhao C, Zheng Y, $\mathrm{Li} \mathrm{H}$, et al: Mitochondrial DAMPs increase endothelial permeability through neutrophil dependent and independent pathways. PLoS One 2013;8:e59989.

130 dos Santos CC, Han B, Andrade CF, Bai X, Uhlig S, Hubmayr R, et al: DNA microarray analysis of gene expression in alveolar epithelial cells in response to TNFalpha, LPS, and cyclic stretch. Physiol Genom 2004;19:331342.

131 Cabrera-Benitez NE, Parotto M, Post M, Han B, Spieth PM, Cheng WE, et al: Mechanical stress induces lung fibrosis by epithelial-mesenchymal transition. Crit Care Med 2012;40: 510-517.

132 Heise RL, Stober V, Cheluvaraju C, Hollingsworth JW, Garantziotis S: Mechanical stretch induces epithelial-mesenchymal transition in alveolar epithelia via hyaluronan activation of innate immunity. J Biol Chem 2011;286: 17435-17444.

133 Bhattacharya J, Matthay MA: Regulation and repair of the alveolar-capillary barrier in acute lung injury. Annu Rev Physiol 2013;75:593615.

134 Chapman HA, Li X, Alexander JP, Brumwell A, Lorizio W, Tan K, et al: Integrin a $6 \beta 4$ identifies an adult distal lung epithelial population with regenerative potential in mice. J Clin Invest 2011;121:2855-2862.

135 Hayes M, Curley G, Ansari B, Laffey JG: Clinical review: stem cell therapies for acute lung injury/acute respiratory distress syndrome hope or hype? Crit Care 2012;16:205.

136 Cardenes N, Caceres E, Romagnoli M, Rojas M: Mesenchymal stem cells: a promising therapy for the acute respiratory distress syndrome. Respiration 2013;85:267-278. 